\title{
Microbial diversity in UASB reactors
}

\author{
Zafar Iqbal Bhatti(a), Kenji Furukawa(b) and Masanori Fujita(c) \\ (a)Institute of Environmental Sciences and Engineering, National University of \\ Sciences and Technology, Tamizuddin Road, Lalkurti, Rawalpindi, Pakistan \\ (b)Department of Architecture and Civil Engineering, Kumamoto University, \\ Kurokami 2-39-1, Kumamoto 860, Japan, and, \\ (c)Department of Environmental Engineering, Faculty of Engineering, Osaka \\ University, 2-1 Yamadaoka, Suita, Osaka 565, Japan
}

\begin{abstract}
Upflow anaerobic sludge blanket (UASB) process is now widely used for the treatment of industrial wastes. Immobilized methanogenic granules play a vital role in such a process. In this study, microbial diversity of these granules from five different full-scale and laboratory UASB reactors operating under different conditions was investigated. The results were categorized on the basis of four different cases of operational and environmental conditions. Predominant methanogens in granules operating under a specific set of operational or environmental conditions were generally different from each other. The results indicated that microorganisms resembling those of the genera Methanobacterium, Methanobrevibacter, Methanothrix and Methanosarcina dominated the granules. However, a variety of other species co-existed with the dominant methanogens. The presence of diverse bacterial groups manifested a unique property of the granules of seeding and fast start-up of other UASB reactors.
\end{abstract}

Key words: UASB, microbial diversity, methanogens, scanning electron microscopy, operational and environmental conditions.

\section{INTRODUCTION}

High rate anaerobic wastewater treatment processes like the upflow anaerobic sludge blanket(UASB), expanded/fluidized bed, and anaerobic filter have many advantages over conventional aerobic wastewater treatment processes. Being simple in operation and low in cost, their applicability is particularly feasible in developing countries. The UASB process is the most widely used anaerobic wastewater treatment process especially for stabilizing high strength industrial organic wastes. Hundreds of full-scale UASB plants are reported to be operating worldwide (refs. $1 \& 2$ ).

The UASB process utilizes the principle of bacterial self-immobilization known as granulation. The success of UASB reactors to treat high-strength industrial organic wastes generally depends upon the formation of these stable granules. The mechanism governing formation of granular sludges was not clearly understood till recently and many questions remain unanswered. We have recently provided an insight into granule formation (ref. 3). Because of their diverse nature, there has been great interest in the microbial characterisics of granular sludges (refs $4,5,6 \& 7$ ).

This study focuses on the investigation of microbial diversity in granular sludges obtained from five different full-scale and laboratory UASB reactors treating industrial wastes under different operational and environmental conditions. The results are categorized on the basis of four such cases.

\section{MATERIAL AND METHODS}

Granular sludges were obtained from the full-scale UASB reactors under maximum possible anaerobic conditions. Samples of granular sludges from the laboratory UASB reactors were obtained under a nitrogen environment. All samples were preserved in anaerobic conditions at $4^{\circ} \mathrm{C}$ until the time of preparing the samples 
for scanning electron microscopy (SEM). SEM was performed on a number of individual granules chosen at random from each sample and was carried out according to the procedures elaborated previously (ref. 8). All

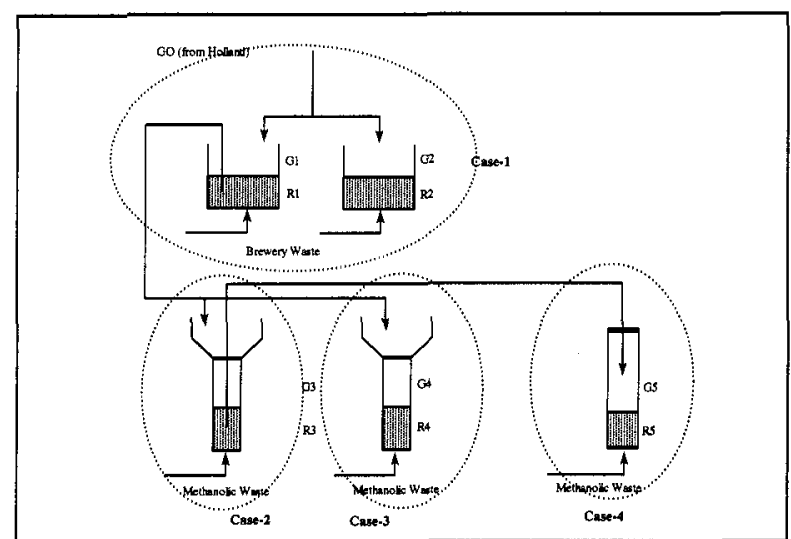

Fig.1. Schematic Diagram of the Reactors and their Sequence of Seeding other analyses were carried out according to Standard Methods (ref. 9).

\section{RESULTS AND DISCUSSION}

Laboratory UASB studies were carried out over a period of three years. Laboratory UASB reactors were either seeded with the granules obtained from a full-scale UASB reactor or with the granules transferred from one laboratory UASB reactor to the other. The full-scale reactors had been treating brewery waste for a long period prior to our laboratory studies. The reactors and the sequence of seeding is schematically illustrated in Fig. 1. Some physical and chemical properties of the granular sludges from these reactors are listed in Table 1.
TABLE 1. Some Physical and Chemical Characteristics of the Granular Sludges.

\begin{tabular}{|c|c|c|c|c|c|c|c|c|}
\hline $\begin{array}{l}\text { Granular } \\
\text { sludge } \\
\text { sample } \\
\end{array}$ & $\begin{array}{l}\text { Avg. } \\
\text { size } \\
(\mathrm{mm}) \\
\end{array}$ & $\begin{array}{l}\text { Avg. settling } \\
\text { velocity } \\
\left(\mathrm{cm} . \mathrm{s}^{-1}\right)\end{array}$ & $\begin{array}{c}\text { Ash } \\
\text { content } \\
(\%)^{2}\end{array}$ & Color & $\begin{array}{c}\text { Solids } \\
\text { content } \\
(\%)\end{array}$ & $\begin{array}{c}\text { Carbohy- } \\
\text { drates } \\
\text { (\% TSS) }\end{array}$ & $\begin{array}{c}\begin{array}{c}\text { Nucleic } \\
\text { acids } \\
\text { (\% TSS) }\end{array} \\
\end{array}$ & $\begin{array}{l}\text { Proteins } \\
\text { (\% TSS) }\end{array}$ \\
\hline G1 & $2 \sim 3$ & 4.19 & 20.6 & black & 12.2 & 1.7 & 2.5 & 13.2 \\
\hline G2 & $2 \sim 3$ & 2.10 & 11.0 & brown & 11.8 & 2.7 & 5.1 & 16.3 \\
\hline G3 & $2 \sim 3$ & $-^{\mathrm{b}}$ & - & blackish & - & - & - & - \\
\hline G4 & $2 \sim 3$ & - & - & black & - & - & - & - \\
\hline & dat & $\begin{array}{l}\text { e/values } \\
\text { lable (-) }\end{array}$ & & $\mathrm{d} / \mathrm{w}$ & & & & \\
\hline
\end{tabular}

Granules from all the reactors were obtained and subjected to scanning electron microscopy. The five UASB reactors were operated under different conditions so as to investigate the relative microbial changes. The operational and environmental conditions of the reactors are given in Table 2.

TABLE 2. Summary of Operational and Environmental Conditions in the UASB Reactors

\begin{tabular}{|c|c|c|c|c|c|c|c|c|c|c|}
\hline \multirow[b]{2}{*}{$\begin{array}{l}\text { Case } \\
\text { No }\end{array}$} & \multirow[b]{2}{*}{$\begin{array}{l}\text { Type of } \\
\text { reactor }\end{array}$} & \multirow[b]{2}{*}{$\begin{array}{l}\text { Volume } \\
\text { of } \\
\text { reactor }\end{array}$} & \multirow[b]{2}{*}{$\begin{array}{l}\text { Period of } \\
\text { operation }\end{array}$} & \multicolumn{2}{|c|}{ Substrate } & \multicolumn{3}{|c|}{ Operational conditions } & \multirow[b]{2}{*}{$\begin{array}{c}\text { Seed } \\
\text { granules }\end{array}$} & \multirow[b]{2}{*}{$\begin{array}{l}\text { Modified } \\
\text { granules }\end{array}$} \\
\hline & & & & $\begin{array}{c}\text { Seed } \\
\text { granules }\end{array}$ & $\begin{array}{c}\text { Test } \\
\text { granules }\end{array}$ & $\mathrm{pH}$ & $\begin{array}{l}\text { Temp } \\
\left({ }^{\circ} \mathrm{C}\right)\end{array}$ & $\begin{array}{l}\text { Organic loading } \\
\text { rate } \\
\left(\mathrm{Kg} . \mathrm{COD} . \mathrm{m}^{-3} . \mathrm{d}\right)\end{array}$ & & \\
\hline \multirow[t]{2}{*}{1} & $\begin{array}{l}\text { Full- } \\
\text { scale } \\
\text { (R1) }\end{array}$ & - & Years & $\begin{array}{l}\text { Alcoholic } \\
\text { waste }\end{array}$ & $\begin{array}{c}\text { Brewery } \\
\text { waste }\end{array}$ & $\sim 7.0$ & $\sim 30$ & 16.8 & G0 & Gl \\
\hline & $\begin{array}{l}\text { Full- } \\
\text { scale } \\
\text { (R2) }\end{array}$ & $3800 \mathrm{~m}^{3}$ & Years & $\begin{array}{c}\text { Alcoholic } \\
\text { waste }\end{array}$ & $\begin{array}{c}\text { Brewery } \\
\text { waste }\end{array}$ & $\begin{array}{l}7.7- \\
7.9\end{array}$ & $\sim 30$ & 6.4 & G0 & G2 \\
\hline 2 & $\begin{array}{l}\text { Lab- } \\
\text { scale } \\
\text { (R3) }\end{array}$ & 6.51 & 410 days & $\begin{array}{c}\text { Brewery } \\
\text { waste }\end{array}$ & $\begin{array}{c}\text { Methanolic } \\
\text { waste }\end{array}$ & 7.0 & 37 & 15.0 (avg) & Gl & G3 \\
\hline 3 & $\begin{array}{l}\text { Lab- } \\
\text { scale } \\
\text { (R4) }\end{array}$ & 4.251 & 250 days & $\begin{array}{l}\text { Brewery } \\
\text { waste }\end{array}$ & $\begin{array}{l}\text { Methanolic } \\
\text { waste }\end{array}$ & $\begin{array}{l}5.5- \\
6.0\end{array}$ & $20-30$ & $7.0-8.0$ (avg) & G1 & G4 \\
\hline 4 & $\begin{array}{l}\text { Lab- } \\
\text { scale } \\
\text { (R5) }\end{array}$ & 2.51 & 180 days & $\begin{array}{l}\text { Methanolic } \\
\text { waste }\end{array}$ & $\begin{array}{l}\text { Methanolic } \\
\text { waste }\end{array}$ & 7.0 & 37 & $13.0(\mathrm{avg})$ & R3 floc & G5 \\
\hline
\end{tabular}



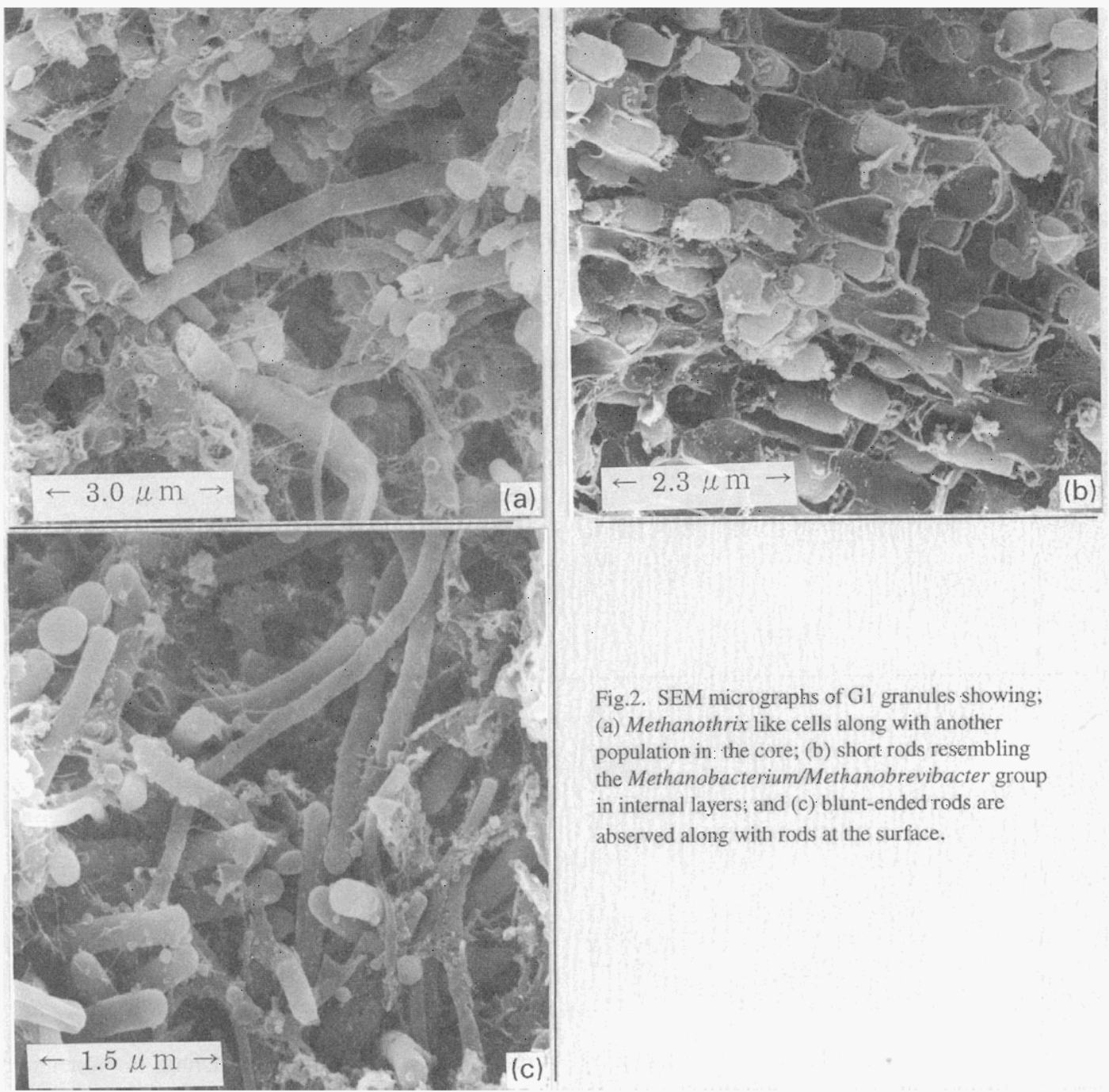

Fig.2. SEM micrographs of G1 granules showing; (a) Methanothrix like cells along with another population in: the core; (b) short rods resembling the Methanabacterium/Methanobrevibacter group in internal layers; and (c) blunt-ended rods are abserved along with rods at the surface.

\section{Microbial Diversity}

Microbial populations were investigated in the core and exterior layers and on the surface of the granules. Characteristics of the 4 case studies are prsented in Table 2.

Case 1. Full scale reactors, called R1 and R2, were seeded with the same granular sludge imported from Holland. Both the reactors treated brewery waste under almost identical environmental conditions. However, R2 was operated at a low organic loading rate. After years of operation, G1 and G2 granules from reactors $\mathrm{R} 1$ and $\mathrm{R} 2$ respectively showed different characteristics as listed in Table 1. Dominant microbial populations also differed as shown in the SEM micrographs of Figs. 2 and 3.

G1 granules were dominated by Methanothrix like cells (Fig. 2a) in the core and at the surface (Fig. 2c) but by Methanobacterium resembling cells in the interior (Fig. 2b). On the contrary, G2 granules were dominated by blunt-ended sheathed rods consistent with the appearance of Methanothrix species in the core and the interior (Fig. 3a and b). Heterogeneous population was only observed at the surface (Fig. 3c) which included short and long rods, filaments and cocci. 


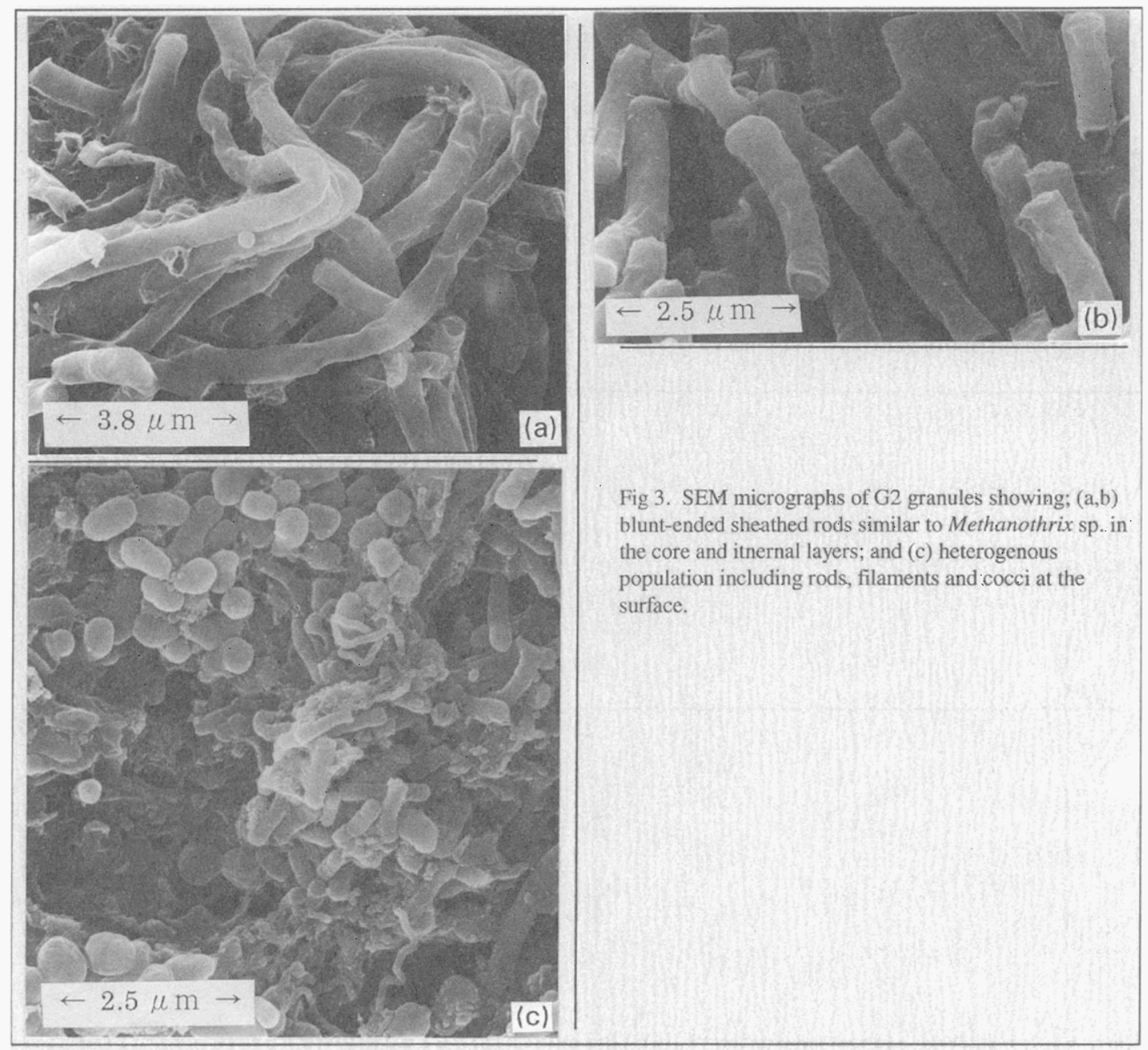

The bulk of granules in G1 was dominated by round-ended short rods resembling in appearance Methanobacterium and/or Methanobrevibacter species. In contrast, G2 granules were dominated by Methanothrix like microorganisms. This difference in microbial population was attributed to the difference in organic loading rate since no other apparent difference in operational or environmental conditions existed.

Case 2 In Case 2, the effect of substrate on the microbial diversity was investigated. G1 granules from R1 were seeded in a laboratory scale reactor (R3) which was operated on synthetic methanolic waste. After 410 days of continuous operation, the microbial population had changed in the seeded granules. These altogether different granules were called G3. Other new granules were also formed which resembled to G3 in microbial diversity. The Methanobacterium/Methanobrevibacter like bacteria in G1 were replaced by single or paired cocci in the interior layers and at the surface as seen in the electron microgtaphs of Fig. $4 \mathrm{a}$ and b respectively. Their number was less in the core as observed in Fig. 4c. Except for a small core region, G3 granules were dominated by coccal forms of organisms resembling in appearance Methanosarcina species. It was, therefore, concluded that different substrate resulted in different microbial populations. 


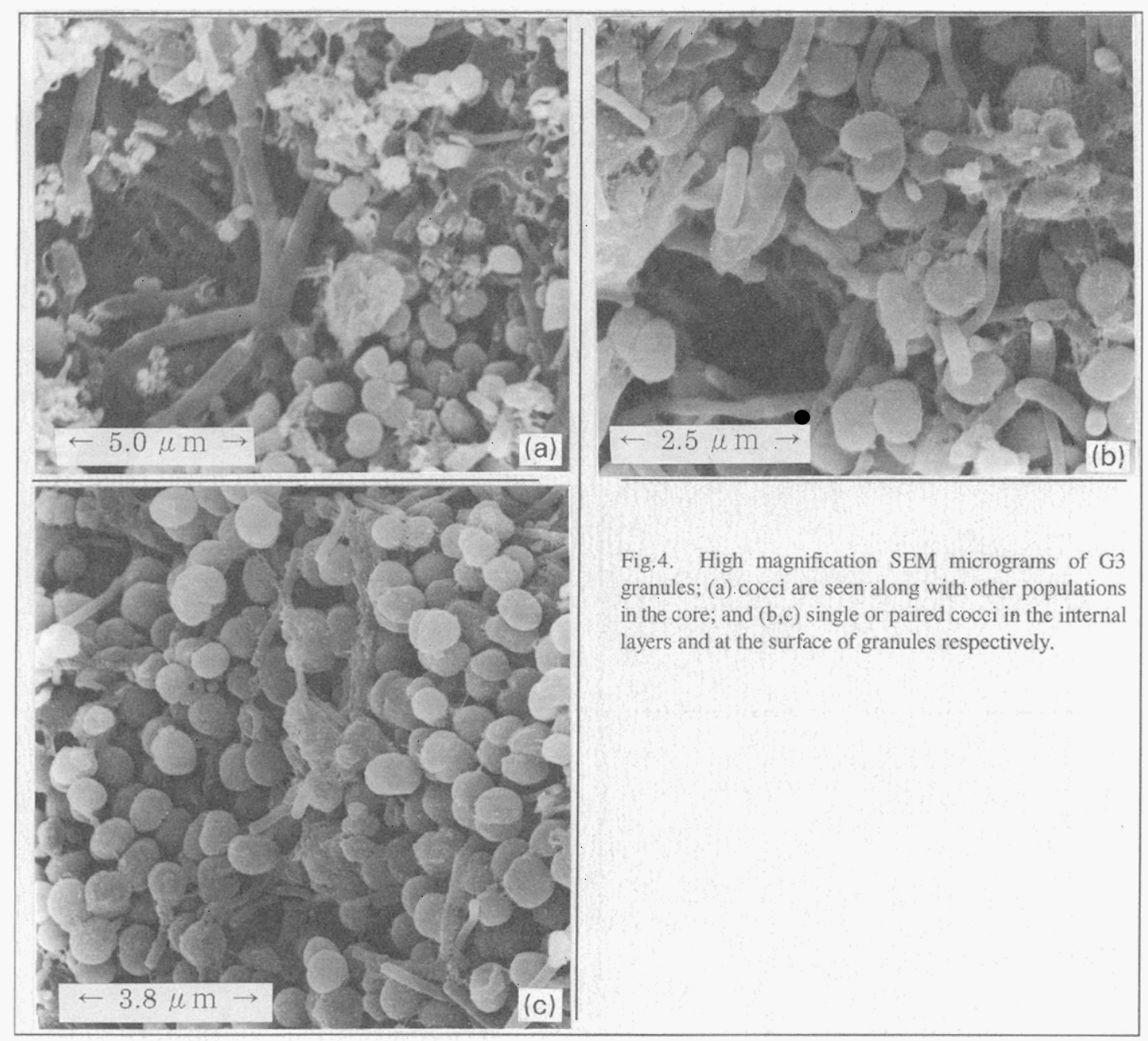

Case 3. In Case 2, UASB reactor was operated on a methanolic waste at a $\mathrm{pH}$ value around 7.0. In case 3 , another UASB reactor (R4) was operated on the same substrate, i.e. methanolic waste but at lower $\mathrm{pH}$ values for about 250 days of continuous operation. This reactor was seeded with granular sludge obtained from reactor R1. Thus the difference in environmental conditions between R3 and R4 was mainly the difference in the $\mathrm{pH}$ value. In this reactor, no external alkali was added to maintain neutral $\mathrm{pH}$ conditions. After an initial start-up period, the reactor maintained a self-operating $\mathrm{pH}$ range of 5.5-6.0. SEM performed on the granules (G4) obtained from this reactor manifested the complete dominance of round-ended short rods resembling in appearance Methanobacterium and/or Methanobrevibacter species throughout the granule as observed in electron micrographs of Fig. 5 a and b. However, onjy the surface of these granules showed long rods in addition to short rods (Fig. 5c). Though the substrate was the same, a comparison of G3 and G4 granules indicated that these granules were dominated by an altogether different species, i.e. cocci in G3 and rods in G4. This result suggested that a pH difference resulted in different dominating species and may furthersuggest the prevalence of different substrate degradation pathways. 


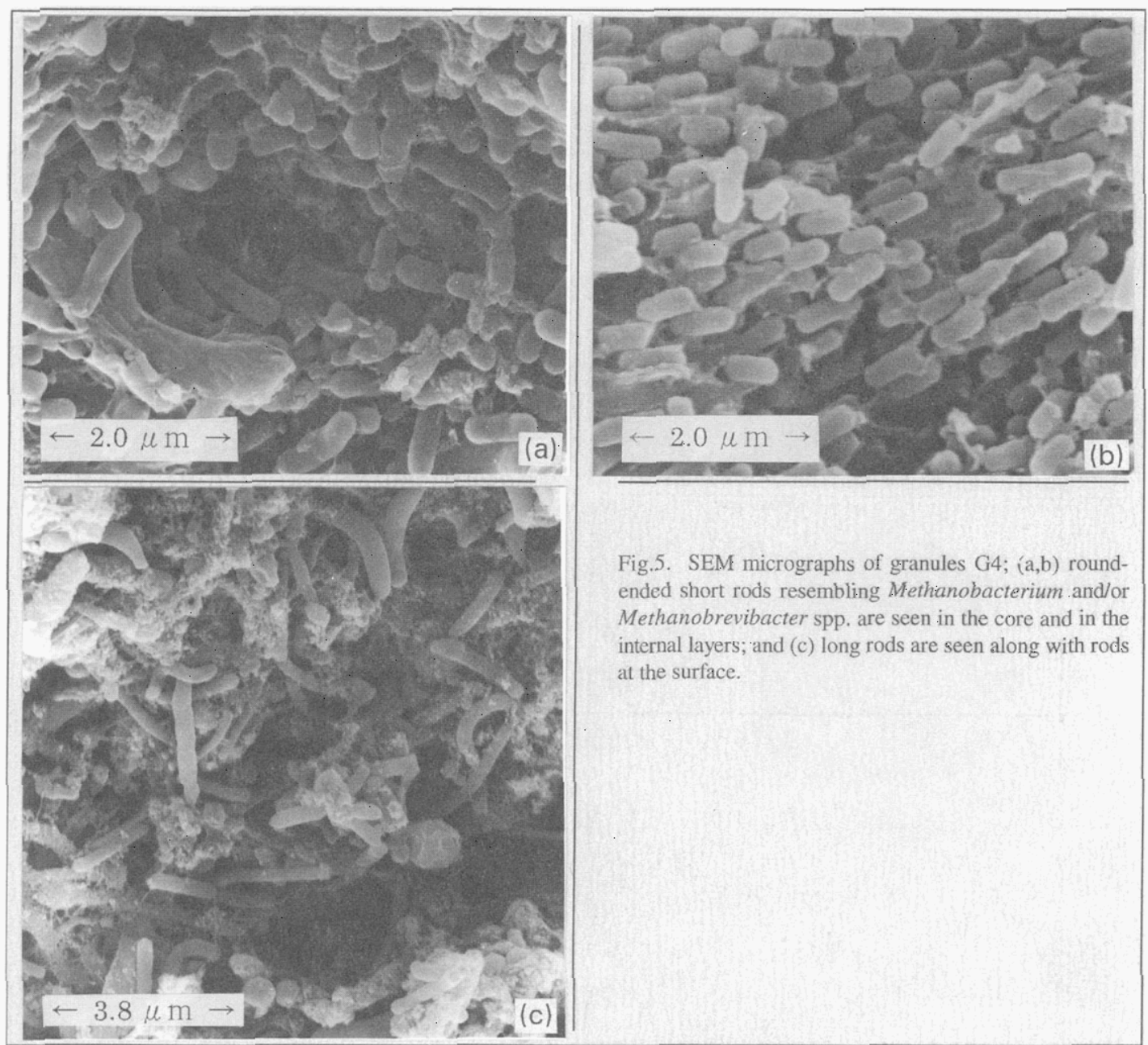

Case 4. The mechanism of granulation was investigated in Case 4 by cultivating new granures. Supernatant sludge from R3 consisting of fine flocs was seeded into a 2.5 liter laboratory reactor called R5. The substrate was a synthetic methanolic waste. $1 \sim 2 \mathrm{~mm}$ discrete granules developed after 180 days of continuous operation. These granules (G5) were dominated by single and paired cocci both in the core and at the surface, as observed in the SEM micrographs of Fig. 6a, b and c respectively. Some large granules 4 -5 mm in diameter were also formed in this reactor but because of their low settling velocity, washed out of the reactor. These granules contained bunches of coccoidal microorganisms resembling of Methanosarcina, as seen in Fig. 7a. Some of these gramules consisted of paired cocci linked by some form of extracellular, polymeric material as observed in Fig. $7 \mathrm{~b}$. 


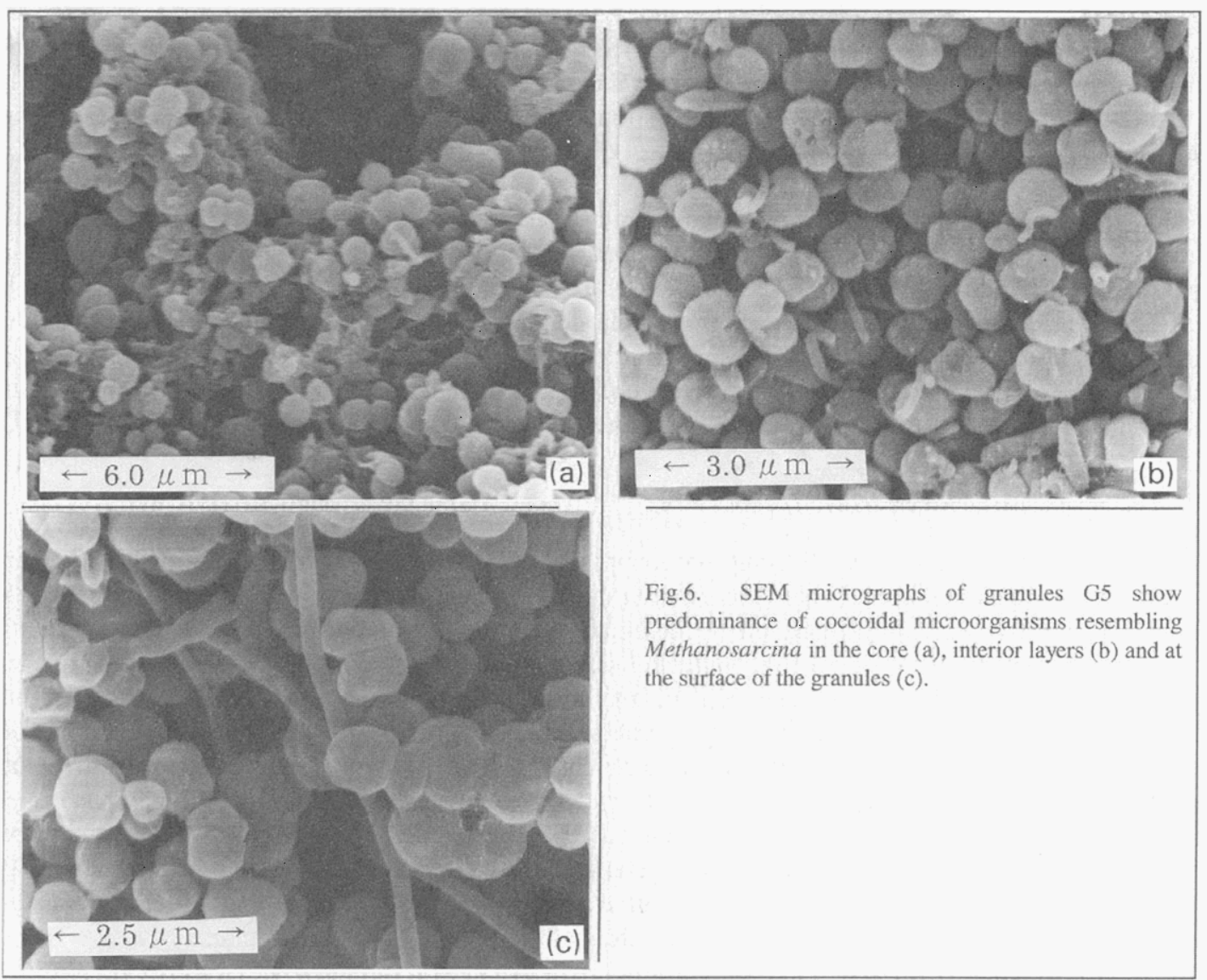

In all the cases, granules were dominated by different genera of methanogens although a variety of species coexisted with the dominant methanogens. In general, the predominating genera of methanogens were those resembling in appearance Methanothrix, Methanobacterium, Methanobrevibacter and Methanosarcina. The
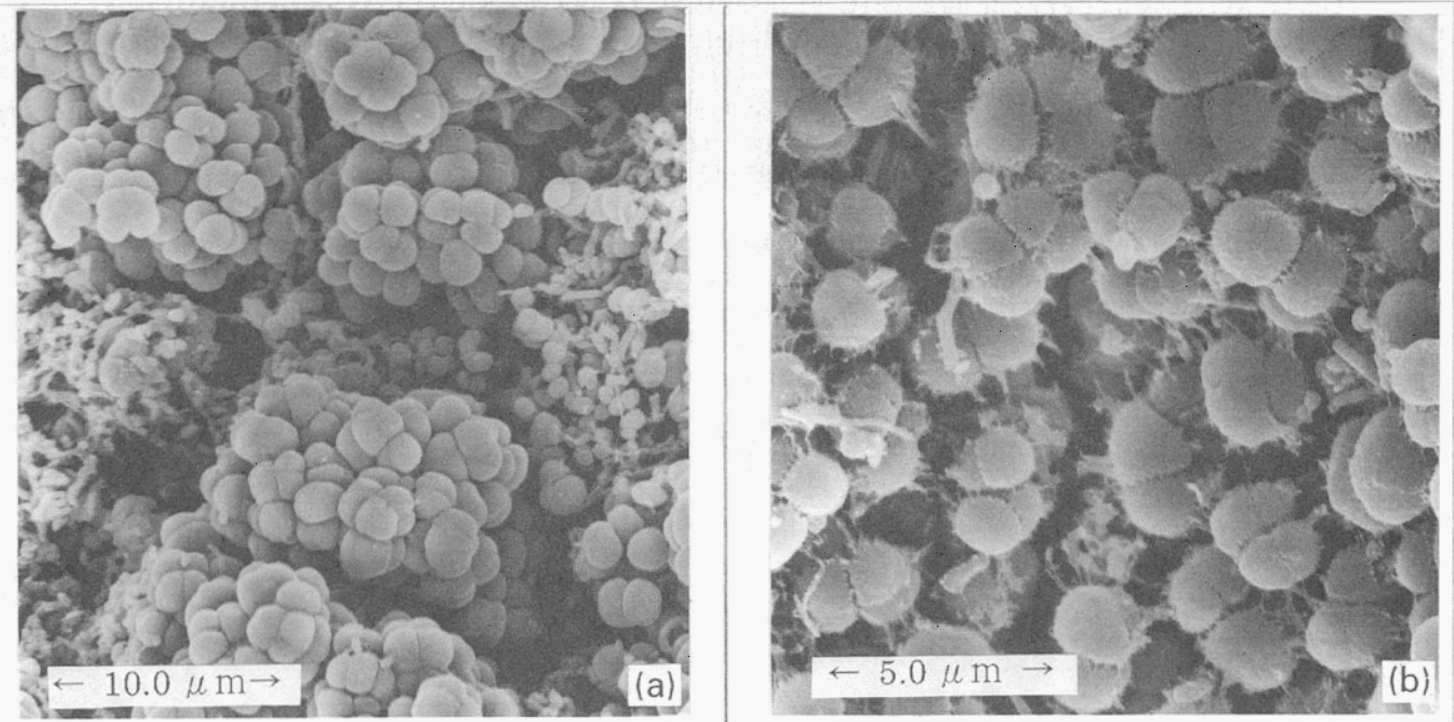

Fig 7. SEM microgaphs of big granules washed out of the reactor show bunches of coccoidal organisms resembling Methanosarcina (a) and paired cocci, also resembling Methanosarcina linked by extracellutar polymeric material (b) 
dominating methanogens resembled each other in $\mathrm{G} 1$ and $\mathrm{G} 4$ granules although the substrate was different. The dominant microbial population in G3 resembled that of G5 granules having developed on the same substrate and under almost identical environmental conditions. The non-resemblance of microbial populations of G1 and G2 granules indicated a strong effect of organic loading rate whereas similarities between $\mathrm{G} 3$ or G5 and G4 suggested a strong effect of $\mathrm{pH}$.

The granular sludges consisted of diverse bacterial groups. The results suggested that specific microorganisms were selected according to the prevailing operational and environmental conditions. Where optimum conditions existed, the organisms grew at a fast rate and eventually dominated the granules. In all the cases seeding of unacclimatized granules neither slowed the stabilization process nor resulted in process failure, but, on the contrary, enhanced the fast start-up of reactors. This phenomenon suggested a unique property of granular sludges to quickly acclimatize to different operational and environmental conditions. Thus, a major disadvantage of late start-up in anaerobic reactors seem to be overcome by granular sludges.

\section{CONCLUSIONS}

From the results of this study, the following conclusions were drawn: (i) Granular sludges grown on different waste streams or under different operational or environmental conditions show different characteristics and microbial diversity; (ii) In general, the predominant genera of methanogens in granular sludges are Methanobacterium, Methanobrevibacter, Methanothrix and Methanosarcina; (iii) Organic loading rate has a strong effect on the selection of methanogenic microorganisms. Differences in the organic loading rate with the same substrate may result in different microbial populations; (iv) Granular sludges operating under same substrate and same $\mathrm{pH}$ values will manifest no change in microbial populations provided that other conditions are also identical; (v) $\mathrm{pH}$ has a strong effect on the dominating methanogens. Different $\mathrm{pH}$ values, even with the same substrate, will tend to alter the bacterial populations; (vi) Diverse bacterial groups coexist in granular sludges. Favorable operational and environmental conditions will select the dominant group bacteria. This is a unique and useful property of granular sludges to seed different UASB reactors treating different waste streams. This property can reduce the start-up periods of UASB reactors.

\section{REFERENCES}

1. Pol, L. H. and Lettinga, G. (1986). New technologies for anaerobic wastewater treatment. Wat. Sci. Technol. , 18, 41-53.

2. Fang, H. H. P. and Chui, H. K. (1993). Maximum COD loading capacity in UASB reactors at $37^{\circ}$-C. ASCE J. Env. Eng., 119, 103-119.

3. Bhatti, Z. I., Furukawa, K. \& Fujita, M. (1995). Methanogenic granular sludge formation in an upflow anaerobic sludge blanket reactor treating synthetic methanolic waste. World J. Microbiol. Biotechnol, 11, 631-637.

4. Forster, C. F. (1990). Anaerobic upflow sludge blanket reactors: aspects of their microbiology and their chemistry. $J$. Biotechnol., 17, 221-232.

5. Visser, F. A., van Lier, J. B., Macario, A. J. L. \& deMacario, E. C. (1991). Diversity and population dynamics of methanogenic bacteria in a granular consortium. Appl. Environ. Microbiol., 57, 1728-1734.

6. Fukuzaki, S., Chang, Y., Nishio, N. \& Nagai, S. (1991). Characteristics of granular methanogenic sludge grown on lactate in a UASB reactor. J. Ferm. Bioeng., 72, 465-472.

7. Bhatti, Z. I., Furukawa, K. \& Fujita, M. (1995). Comparative composition and characteristics of methanogenic granular sludges treating industrial wastes under different conditions. J. Ferm. Bioeng., 79, 273-280.

8. Bhatti, Z. I., Furukawa, K. \& Fujita, M. (1993). Treatment performance and microbial structure of a granular consortium handling methanolic waste. J. Ferm. Bioeng., 76, 218-223.

9. APHA, AWWA \& WPCF (1985). Standard methods for the examination of waters and wastewaters. 16th ed. Washington DC. 